\title{
Foods of Free-Roaming Horses in Southern New Mexico
}

\section{RICHARD M. HANSEN}

Highlight: Seasonal foods of free-roaming wild horses were determined in southern New Mexico by microhistological analyses of fecal samples. The most important forages consumed annually by wild horses were Russianthistle (29\%), dropseed (21\%), mesquite (16\%), and Junegrass (12\%). Seasonal differences in the percentages of the diets were found for mesquite, Junegrass, and saltbush.

The number of free-roaming horses has been increasing in the West in recent years (Cook, 1975). Wherever there is a need to manage horses on National Resource Lands it is necessary to determine their food habits to prevent the destruction of plant cover and to maintain maximum herbage production.

The objective of this paper was to report the seasonal foods of a group of free-roaming horses which lived on the White Sands Missile Range in southern New Mexico.

\section{Methods}

Collections of feral horse fecal samples were made concurrently with a study by Saiz and Decker (1975) on the ecology and food habits of the Gemsbok (Oryx gazella) on the White Sands Missile Range in southern New Mexico. A minimum of 50 different subsamples was collected from fresh moist dung each month from June 1973 through May 1974. Subsamples were composited on an equal dry weight basis into a monthly sample. The percentages of the classified fragments of plants in the sample were quantified by microhistological procedure (Sparks and Malechek, 1968). Twenty microscope slides were made per composited fecal sample and 20 fields were examined, for a total of 400 fields per sample. The percentage of forage categories may nearly approximate the percentage dry weights in the diet (Dearden et al., 1975; Todd and Hansen, 1973).

A vegetation survey was not made. Horse dung was sampled in the northeast part of the White Sands Missile Range in the Salt Creek drainage, the only permanent source of water. The vegetation type is typical desert grassland.

The monthly diets were averaged to obtain seasonal food habits (summer = July, August, September; fall = October, November, December; winter = January, February, March; spring $=$ April, May, June). Scientific names and common names of food are used in the table.

\section{Results and Observations}

There were 20 different genera of plants and a few unidentified plants found in the diets of feral horses (Table 1). Russianthistle (29\%), dropseed (21\%), mesquite (16\%), Junegrass $(12 \%)$, spangletop $(6 \%)$, and saltbush $(5 \%)$ were the staple and most important foods. Wheatgrass and grama were important foods only in the spring and summer. Saltbush was eaten from fall through spring. Mesquite pods and leaves made up $53 \%$ of the diet in September and only $2 \%$ (leaves) in March. Glendening and Paulsen (1955) reported that horses were fond of velvet mesquite beans on most southern Arizona ranges. They believed horses may contribute to the spreading and establishment of mesquite by eliminating seeds in their droppings.

The horse diets in this study contained a lower percentage

The author is professor, Range Science Department, Colorado State University, Fort Collins 80523 .

This study has been supported by funds from the Bureau of Land Management and Colorado State University Experiment Station Project 1069. The author is grateful to Terry Foppe and Mary Gilhert for the laboratory work and Richard Saiz for the sample collections.

Manuscript received October 28, 1975.
Table 1. Seasonal percentages of foods in diets of free-roaming horses, White Sands Missile Range, southern New Mexico. ${ }^{1}$

\begin{tabular}{lcccc}
\hline \multicolumn{1}{c}{ Principal foods } & Summer & Fall & Winter & Spring \\
\hline Russianthistle (Salsola kali) & 13 & 31 & 42 & 28 \\
Dropseed (Sporobolus spp.) & 27 & 23 & 13 & 20 \\
Mesquite (Prosopis juliflora) & 28 & 22 & 11 & 4 \\
Junegrass (Koeleria cristata) & 5 & 6 & 18 & 19 \\
Spangletop (Leptochloa dubia) & 7 & 5 & 4 & 9 \\
Saltbush (Atriplex spp.) & & 6 & 10 & 5 \\
Wheatgrass (Agropyron spp.) & 5 & $<1$ & $<1$ & 6 \\
Grama (Bouteloua spp.) & 5 & 1 & $<1$ & 3 \\
Muhly (Muhlenbergia spp.) & 6 & $<1$ & & $<1$ \\
Bristlegrass (Setaria macrostachya) & 3 & $<1$ & & 1 \\
\hline
\end{tabular}

${ }^{1}$ Other genera occurring in diets were: Andropogon, Aristida, Hilaria, Lycurus, Oryzopsis, Panicum, Artemisia, Lesquerella, Oenotheria, Sphaeralcea, and a few unidentified forbs.

$(50 \%)$ of grasses and grasslikes than I have observed in average horse diets from Montana, Idaho, Nevada, Utah, Wyoming, and Colorado (unpublished records in Composition Analysis Laboratory, Range Science Department, Colorado State University). Very little is known about food habits of horses; and until more information is published, the food preferences of horses cannot be predicted for different range types.

The wild horse population on the White Sands Missile Range was estimated to have been 150 to 200 during the spring of 1974 (Saiz and Decker, 1975). The herd is believed to have originated from feral ranch horses, some still wearing brands. Small herds of 5 to 10 animals moved widely during wet periods when water was available to drink in roadside ditches and shallow depressions. During dry periods the wild horses concentrated near the only available water source, an alkaline stream flowing from springs. The only large animals (except humans) which occurred on the areas used by wild horses were the coyote and the exotic Gemsboks. During the wet seasons, wild horses and Gemsboks occurred together and they appeared to ignore each other except for occasional glances (Saiz and Decker, 1975).

Mesquite, grasses, and Russianthistle are the major foods of both the Gemsboks and wild horses on the study area. The wild horses did not appear to be destroying the range plants or causing range deterioration (Richard Saiz, personal communication). If watering places were developed, the wild horse population might become more widespread; and without a managed herd size, the wild horses could become serious competitors with Gemsboks for forage. Most of the mature mares had colts and there was a wide range in body sizes between the wild horses. The herd was apparently healthy and increasing in numbers at a rapid rate.

\section{Literature Cited}

Cook, C. W. 1975. Wild horses \& burros; a new management problem. Rangeman's J. 2:19-21.

Dearden, B. L., R. E. Pegau, and R. M. Hansen. 1975. Precision of microhistological estimates of ruminant food habits. J. Wildl. Manage. 39:402-407.

Glendening, G. E., and H. A. Paulsen, Jr. 1955. Reproduction and establishment of velvet mesquite as related to invasion of semidesert grasslands. U.S. Dep. Agr. Tech. Bull. 1127.50 p.

Saiz, R. B., and E. Decker. 1975. Ecology and behavior of the gemsbok on the White Sands Missile Range, New Mexico. Final report for Federal Aid Project W-111-R-8, New Mexico Dep. Game and Fish, Santa Fe. 145 p.

Sparks, D. R., and J. C. Malechek. 1968. Estimating percentage dry weight in diets using a microscope technique. J. Range Manage. $21: 264-265$.

Todd, J. W., and R. M. Hansen. 1973. Plant fragments in the feces of bighorns as indicators of food habits. J. Wildl. Manage. 37:363-366. 